\title{
IMMUNOMODULATORY EFFECTS OF TGF- $\beta$ IN THE PATIENTS WITH IMMUNE THROMBOCYTOPENIA
}

\author{
Miloš Kostić1, Tanja Džopalić1 ${ }^{1}$ Nikola Živković2 ${ }^{2}$ Ana Cvetanović3
}

\begin{abstract}
The novel concept of immune thrombocytopenia (ITP) pathogenesis is focused on CD4 ${ }^{+}$ $T$ cells, currently considered indispensable in stimulating $B$ cells to produce anti-platelet antibodies. In this in vitro study, we have investigated $\mathrm{CD}^{+} \mathrm{T}$ cell profiles of ITP patients and immunomodulatory effects of TGF- $\beta$ treatment. CD4 ${ }^{+} \mathrm{T}$ cells were isolated from peripheral blood mononuclear cells of healthy controls and ITP patients. After brief incubation, the levels of $\mathrm{T}$ helper signature cytokines and the number of $\mathrm{T}$ regulatory cells (Tregs) were determined. TGF- $\beta$ immunomodulatory proprieties were analyzed by the alterations in cytokine production of IFNY, IL-4, IL-10, IL-17, and IL-2 and Treg frequency, after six-day treatment. ITP patients had decreased level of IL-4 and IL-10, increased IL-17 level and augmented both IFNY/IL-4 and IL-17/IL-10 ratio. Interestingly, in the six-day $\mathrm{CD}^{+} \mathrm{T}$ cell cultures without TGF- $\beta$, no statistically significant differences in cytokine levels between the control and ITP group were documented, except for IL-10 which was significantly lower. In ITP group treated with TGF- $\beta$, a significant increase of IL-10 as well as a decrease in IL-17/IL-10 ratio was detected, compared to TGF- $\beta$ untreated ITP group. There was also an increase in the Treg frequency. The results of our study suggest that ITP patients have Th1 and Th17 biased cell-mediated immune response that can be corrected by enhanced TGF- $\beta$ signaling. However, it appears that long-term culturing of the $\mathrm{CD}^{+} \mathrm{T}$ cells may not be a suitable experimental model for studying immunomodulating effects in ITP due to dynamic phenotype fluctuations of these cells in ex vivo conditions.
\end{abstract}

Acta Medica Medianae 2020;59(2):05-13.

Key words: immune thrombocytopenia, TGF- $\beta$, immunomodulation, IL-10, IL-17

\begin{abstract}
${ }^{1}$ University of Niš, Faculty of Medicine, Department of Microbiology and Immunology, Niš, Serbia

${ }^{2}$ University of Niš, Faculty of Medicine, Department of Pathology, Niš, Serbia

${ }^{3}$ University of Niš, Faculty of Medicine, Department of Oncology, Niš, Serbia
\end{abstract}

Contact: Miloš Kostić

81 Dr. Zoran Djindjić Blvd., 18000 Niš, Serbia

E-mail: milos.kostic@medfak.ni.ac.rs

\section{Introduction}

Immune thrombocytopenia (ITP) is an autoimmune disease characterized by the reduced platelet number $\left(<100 \times 10^{9} / \mathrm{L}\right)$ due to their enhanced degradation and compromised production, which is often clinically manifested by the hemorrhagic diathesis (1). The majority of ITP patients have various anti-platelet antibodies, mainly directed against membrane bound glycoprotein complexes - GPIIbIIIa and GPIb-IX (2), thereby the breakdown of B cell self-tolerance was considered the central pathological event in the disease pathogenesis. Regarding the nature of auto-antigens and auto-antibodies in ITP, recently, it has become clear that B cells, in order to mount anti-platelet immune response, require the assistance of auto-reactive, platelet specific $\mathrm{CD}^{+} \mathrm{T}$ cells (3-5). Depending on the conditions of the microenvironment, naïve $\mathrm{CD} 4^{+} \mathrm{T}$ cells during initial antigen priming could adopt different polarization states, including Th1, Th2, Th17, Th22, Th9, T regulatory cells, and follicular $T$ helper cells, each with specific cytokine profile and functional characteristics.

Th1 cells are defined as IFNy and IL-2 producing subset of $\mathrm{CD}^{+} \mathrm{T}$ cells that express T-bet as a master regulator, while their differentiation programme is dependant on IL-12 signaling. Th2 cells, on the other hand, predominantly produce IL-4, IL5, and IL-13, express GATA-3 as a master transcription factor and require IL-4 for complete differentiation. The equilibrium between Th1 and Th2 cells is perturbed in numerous immune mediated diseases and ITP is not an exception. Accordingly, ITP was classified as Th1 mediated disorder, based on the higher plasma IFNY/IL-4 ratio, higher blood Th1/Th2 cell ratio and the ratio between the gene expression levels of lineage specific master trans- 
cription factors - T-bet and GATA-3, in peripheral blood mononuclear cells (PBMCs) (6-10). Additionally, many of these parameters were found to be negatively correlated with platelet counts, suggesting pathological relevance of Th1/Th2 immune deviation in the ITP pathogenesis $(9,10)$.

Th17 cells represent a unique subset of CD4 ${ }^{+}$ effector $\mathrm{T}$ cells which in addition to $\mathrm{IL}-17$, produce IL-21 and IL-22. Their differentiation pattern involves the activation of transcription factor RORYT induced by the combination of proinflammatory cytokines IL-6, IL-1, IL-23, and TGF- $\beta$. ITP patients have elevated plasma level of IL-17 and other Th17 associated cytokines - IL-1, IL-6, and IL-23 (11, 12), but also a higher level of RORYT expression in PBMCs and frequency of Th17 cells in the blood (1214). In addition to the aberrant Th17 immune response, both numerical and functional abnormalities of $T$ regulatory cells (Tregs) have been documented in ITP. Tregs are $\mathrm{CD}^{+}{ }^{+} \mathrm{T}$ cell subset expressing the transcription factor FoxP3, which can be induced by a combination of cytokines TGF- $\beta$ and IL2. In contrast to other $\mathrm{CD}^{+} \mathrm{T}$ cell subsets, Tregs upon antigen recognition induce active immunosuppression by producing anti-inflammatory cytokines TGF- $\beta$ and IL-10 or by direct cell to cell contact via inhibitory molecules (negative co-stimulators) CTLA4 and PDL-1. Although decreased in number (15, 16), Tregs isolated from ITP patients also have compromised suppressive functions due to decreased production of TGF- $\beta$ and IL-10, while serum/plasma levels were found to be decreased and positively correlated with the platelet counts (17-20).

One of the essential characteristics of both Th17 cells and Tregs is their plasticity, i.e. the ability to modify their phenotype and acquire the characteristics and functions of other $\mathrm{CD}^{+}{ }^{+} \mathrm{T}$ cell subsets. Although they perform completely opposite functions, Tregs and Th17 cells share a common differentiation pattern involving TGF- $\beta$; however, the definite differentiation fate of activated $\mathrm{CD}^{+}{ }^{+} \mathrm{T}$ cells is determined by additional factors including the TGF- $\beta$ concentration and different microenvironmental stimuli. Specifically, TGF- $\beta$ alone, at higher concentrations, drives $\mathrm{CD}^{+} \mathrm{T}$ cell differentiation towards
Tregs, but at lower concentrations and in the presence of IL- 6 and IL-23, it favors Th17 cell differentiation (21). In ITP, Th17/Treg balance was found to be increased and in the positive correlation with disease activity (22). In accordance with mutual plasticity of these cell lineages, in the tumor microenvironment, Th17 cells were shown to trans-differentiate into Tregs and TGF- $\beta$ involvement in this process was suggested (23). Given that the therapy of many autoimmune diseases, including ITP, is today largely based on non-specific immunosuppression, which entails numerous side effects, this finding could be of particular importance in the treatment of Th17-mediated autoimmune diseases as it opens the possibilities for modulating immune response in terms of Th17 cell conversion to Tregs.

\section{Aim of the study}

The objective of the present in vitro study was to investigate $C D 4^{+} \mathrm{T}$ cell profiles of ITP patients and immunomodulatory effects of TGF- $\beta$ treatment.

\section{Patients and Methods}

Clinical and demographic characteristics of the study participants

The study included 6 subjects, median age 56 (32-69) years, both males and females, subdivided into two groups - a control and ITP group. The control group included 3 healthy volunteers, 2 males and 1 female with normal platelet counts ( $>150 \mathrm{x}$ $\left.10^{9} / \mathrm{L}\right)$. The ITP group included 3 patients, 2 males and 1 female with verified ITP diagnosis according to the criteria established by the International Working Group (24). All the subjects were promptly informed about the relevant details concerning their participation in the study and gave written informed consents. This study was approved by the Ethical Committee of the Clinical Center Niš, Serbia under the identification number $16297 / 5$. Detailed demographic and clinical characteristics of the study participants are shown in Table 1.

Table 1. Demographic and clinical characteristics of the study participants*

\begin{tabular}{||l|cc||}
\cline { 2 - 3 } \multicolumn{1}{c|}{} & $\begin{array}{c}\text { ITP (n=3) } \\
\text { Mean (range) }\end{array}$ & $\begin{array}{c}\text { Control (n = 3) } \\
\text { Mean (range) }\end{array}$ \\
\hline Gender (male/female) & $2 / 1$ & $2 / 1$ \\
Platelet counts (x109/L) & $67(61-69)$ & $39(32-50)$ \\
Duration of the disease (years) & $67(20-110)$ & $294(243-340)$ \\
Phase of the disease & $5(1-10)$ & N/A \\
Therapy & remission & N/A \\
Splenectomy & prednisone & N/A \\
\hline \hline
\end{tabular}

* N/A - Non Applicable 


\section{$C D 4^{+} T$ cell isolation and experimental protocols}

Blood samples (10 $\mathrm{mL})$ were collected by $\mathrm{cu}-$ bital venepuncture using EDTA as an anticoagulant. After sampling, the blood was diluted in RPMI-1640 medium (1:1) and PBMCs were isolated using centrifugation over a Ficoll-Hypaque density gradient (Histopaque-1077; Sigma-Aldrich, St. Louis, Missouri, USA). Upon PBMC isolation, $\mathrm{CD}^{+} \mathrm{T}$ cells were separated as a negative fraction by immunomagnetic sorting using EasySepTM Human CD4 ${ }^{+} \mathrm{T}$ Cell Isolation Kit (Stemcell Technologies, Vancouver, Canada) according to the manufacturer's instructions. The purity of isolated cells was verified by flow cytometry and more then $99 \%$ of isolated cells were $\mathrm{CD}^{+}$ (data not shown). CD4 ${ }^{+} \mathrm{T}$ cells of the control and ITP group were seeded into 24-well plastic plate $1 \times 10^{6}$ cells per well in $1.5 \mathrm{~mL}$ of RPMI-1640 medium supplemented with $2.05 \mathrm{mM}$ L-glutamine, $25 \mathrm{mM}$ HEPES (Sigma-Aldrich, St. Louis, Missouri, USA) and $10 \%$ inactivated fetal bovine serum - FBS (Capricorn Scientific $\mathrm{GmbH}$, Ebsdorfergrund, Germany). In order to evaluate Th profile of the tested subjects, $\mathrm{CD} 4+\mathrm{T}$ cells were incubated at $37^{\circ} \mathrm{C}$ in $5 \% \mathrm{CO}_{2}$ at $95 \%$ humidity for $24 \mathrm{~h}$, and then stimulated with phorbol myristate acetate - PMA (20 ng/mL) and ionomycin (100 ng/mL) (Sigma-Aldrich, St. Louis, Missouri, USA) $8 \mathrm{~h}$ prior supernatant sampling. The remaining cells were used for Treg detection by flow citometry. $\mathrm{CD}^{+} \mathrm{T}$ cells were also incubated with or without human recombinant TGF- $\beta 1$ (3 $\mathrm{ng} / \mathrm{mL})$ (Merck KGaA, Darmstadt, Germany) for 6 days in order to evaluate its immunomodulatory properties.

\section{Sample analyses}

In the collected cell supernatants, IFNy, IL-4, IL-10, IL-17, and IL-2 levels were determined using commercial ELISA kits: Human IFNy Quantikine ELISA Kit, Human IL-4 Quantikine ELISA Kit, Human IL-10 Quantikine ELISA Kit, Human IL-17 Quantikine ELISA Kit, and Human IL-2 Quantikine ELISA Kit (all obtained from R\&D Systems, Minneapolis, Minnesota, USA) according to the manufacturer's instructions. The percentage of Tregs was estimated by flow cytometry. Firstly, cells were washed in stain buffer (BD Biosciences, Franklin Lakes, New Jersey, USA), and then permeabilized and fixed using Transcription Factor Phospho Buffer Set (BD Biosciences, Franklin Lakes, New Jersey, USA). To identify Tregs, antiCD4FITC, anti-CD25APC, and anti-FoxP3PE (all ob- tained from BD Biosciences, Franklin Lakes, New Jersey, USA) antibodies were applied. After washing, sample analyses were performed on BD LSRFortessa using BD FACSDiva ${ }^{\mathrm{TM}}$ software.

\section{Statistical analyses}

All statistical analyses were performed in the GraphPad software (GraphPad Software, LLC, San Diego, CA, USA). The results are presented as the average values \pm standard deviation (SD). The intergroup differences were established using the Student's t-test, and the p values less then 0.05 were considered statistically significant.

\section{Results}

\section{$T$ helper cell profile of ITP patients}

T helper (Th) cell profile of ITP patients was assessed by the level of signature cytokines in the supernatants of CD4+ $\mathrm{T}$ cell cultures. After $24 \mathrm{~h}$ incubation, a statistically significant decrease in the IL-4 and IL-10 was documented as well as an increase in IL-17 level. Both IFNy/IL-4 and IL-17/IL-10 ratios were increased; however, there was no a significant difference in the frequency of Treg (Figure 1).

\section{Immunomodulatory effects of TGF- $\beta$}

Isolated $\mathrm{CD}^{+} \mathrm{T}$ cells from the control and ITP group have been cultured for 6 days with or without TGF- $\beta$. Interestingly, in the cultures without TGF- $\beta$, no statistically significant differences in cytokine levels between the control and ITP group were documented, except for IL-10 which was significantly lower in the ITP group (Figure 2).

In ITP group treated with TGF- $\beta$, a significant increase of IL-10 as well as a decrease in IL-17/IL10 ratio was detected, compared to TGF- $\beta$ untreated ITP group. There was also a marked increase in the frequency of Tregs (Figure 3).

However, after comparing cytokine profile of the ITP group treated with TGF- $\beta$ and untreated control group, a significant decrease in IFNy and IFNY/IL-4 ratio as well as an increase in IL-10 production was found. The frequency of Tregs was significantly higher in TGF- $\beta$ treated ITP group (Figure 4). 

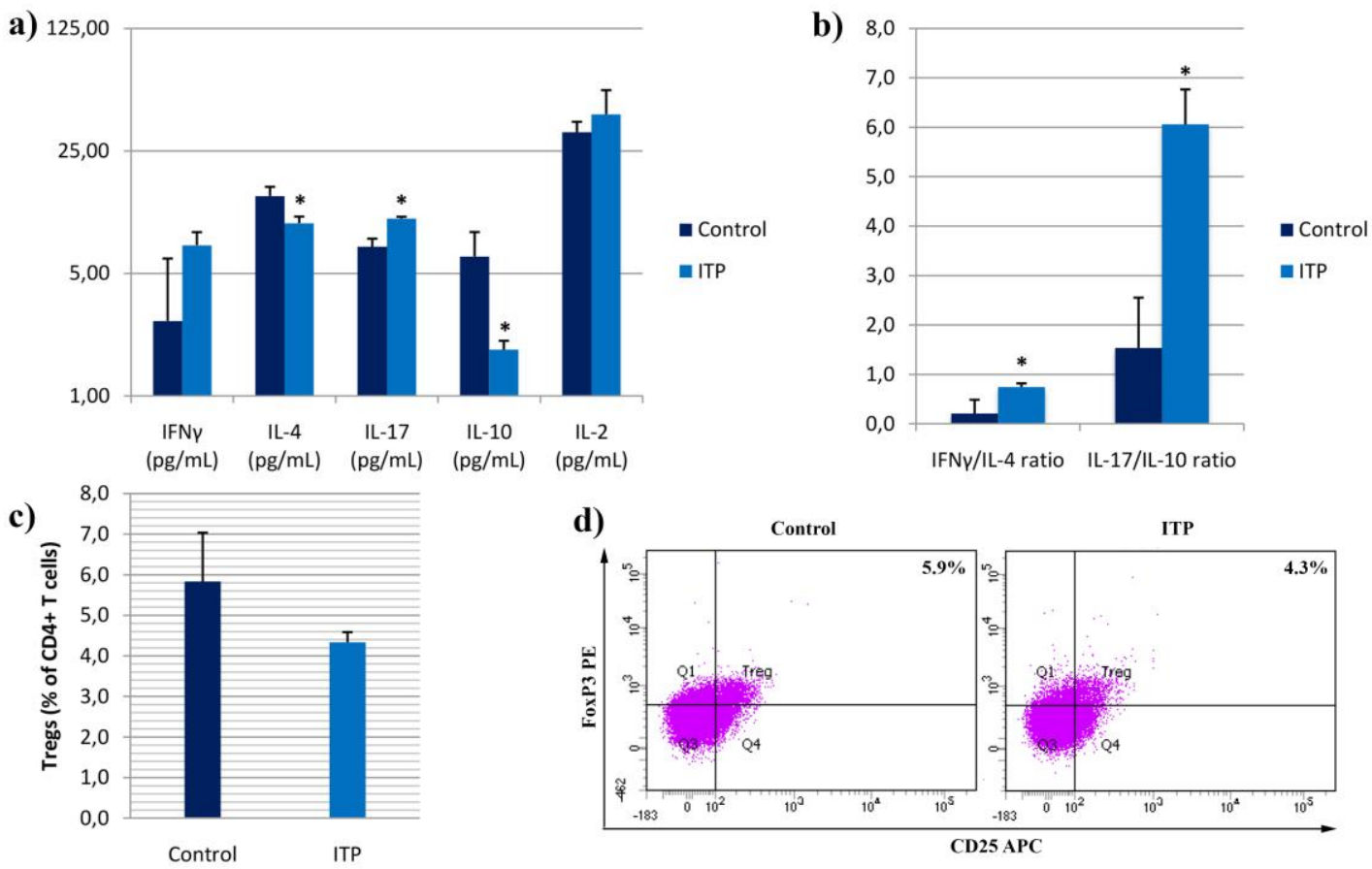

Figure 1. $\mathrm{CD}^{+} \mathrm{T}$ cell profile of ITP patients after $24 \mathrm{~h}$ incubation ${ }^{+}$

${ }^{+} \mathrm{CD} 4{ }^{+} \mathrm{T}$ cells isolated from the control and ITP group were cultured for $24 \mathrm{~h}$ and stimulated with PMA and ionomycin $8 \mathrm{~h}$ prior supernatant sampling. In collected supernatants: a) the level of Th cell signature cytokines was determined; b) IFNy/IL-4 and IL-17/IL-10 ratio was calculated; c) in the remaining cells, Treg frequency was reported; d) representative flow cytometric analyses of CD4 ${ }^{+} \mathrm{T}$ cells in one experiment. (*p $<0.05$ versus control)

a) 125

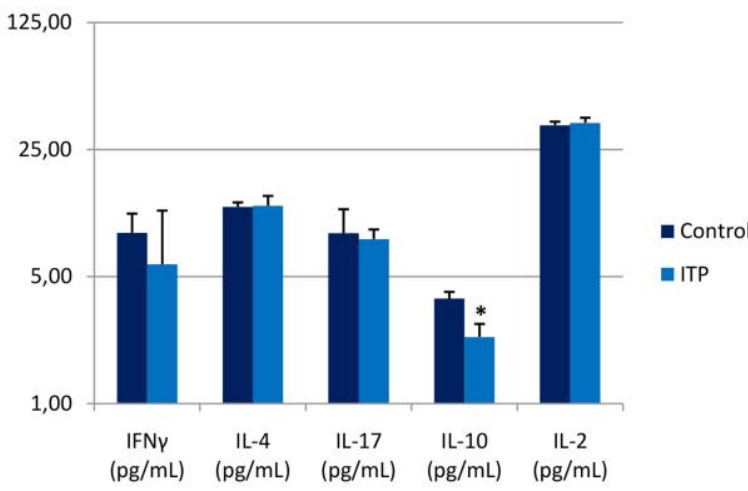

c)
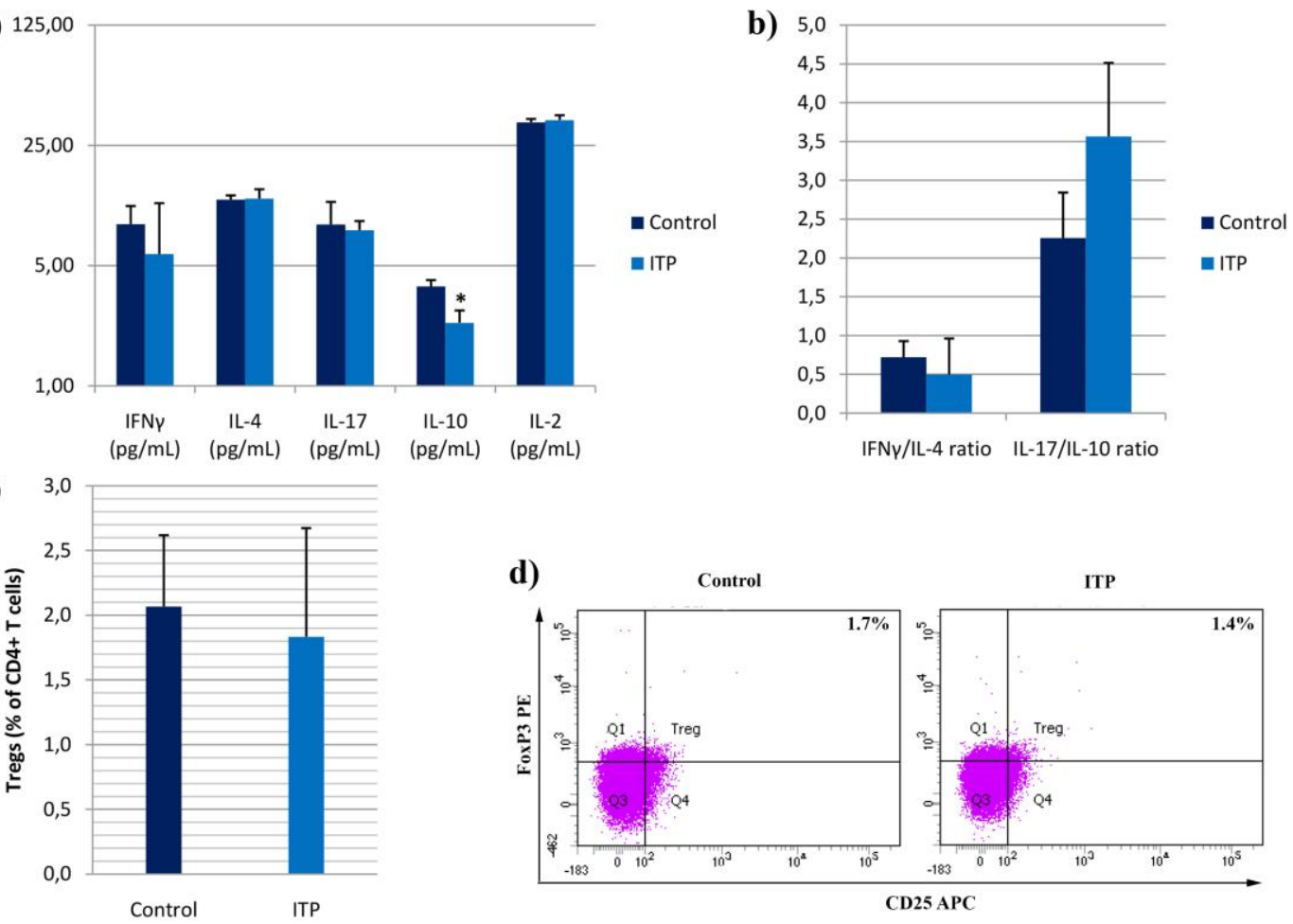

d)
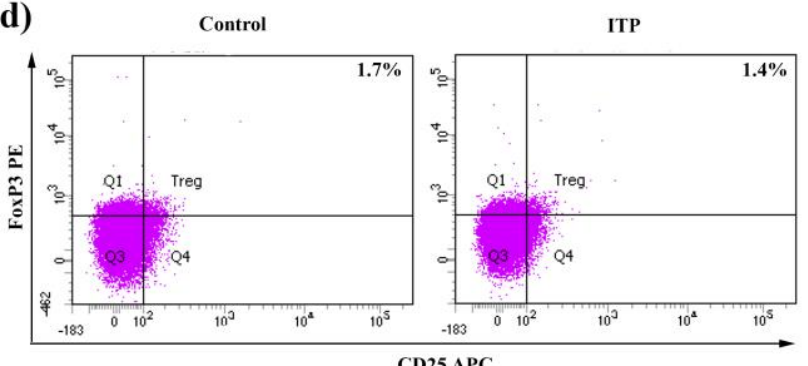

Figure 2. $C D 4^{+}$T cell profile of ITP patients after 6-day incubation without TGF- $\beta^{\ddagger}$

${ }^{\ddagger} \mathrm{CD} 4{ }^{+} \mathrm{T}$ cells isolated from the control and ITP group were cultured without TGF- $\beta$ for 6 days and stimulated with PMA and ionomycin 8h prior supernatant sampling. In collected supernatants: a) the level of Th signature cytokines was determined; b) IFNy/IL-4 and IL-17/IL-10 ratio was calculated; c) in the remaining cells, Treg frequency was reported; d) representative flow cytometric analyses of CD4 ${ }^{+} \mathrm{T}$ cells in one experiment. ( $* \mathrm{p}<0.05$ versus control) 

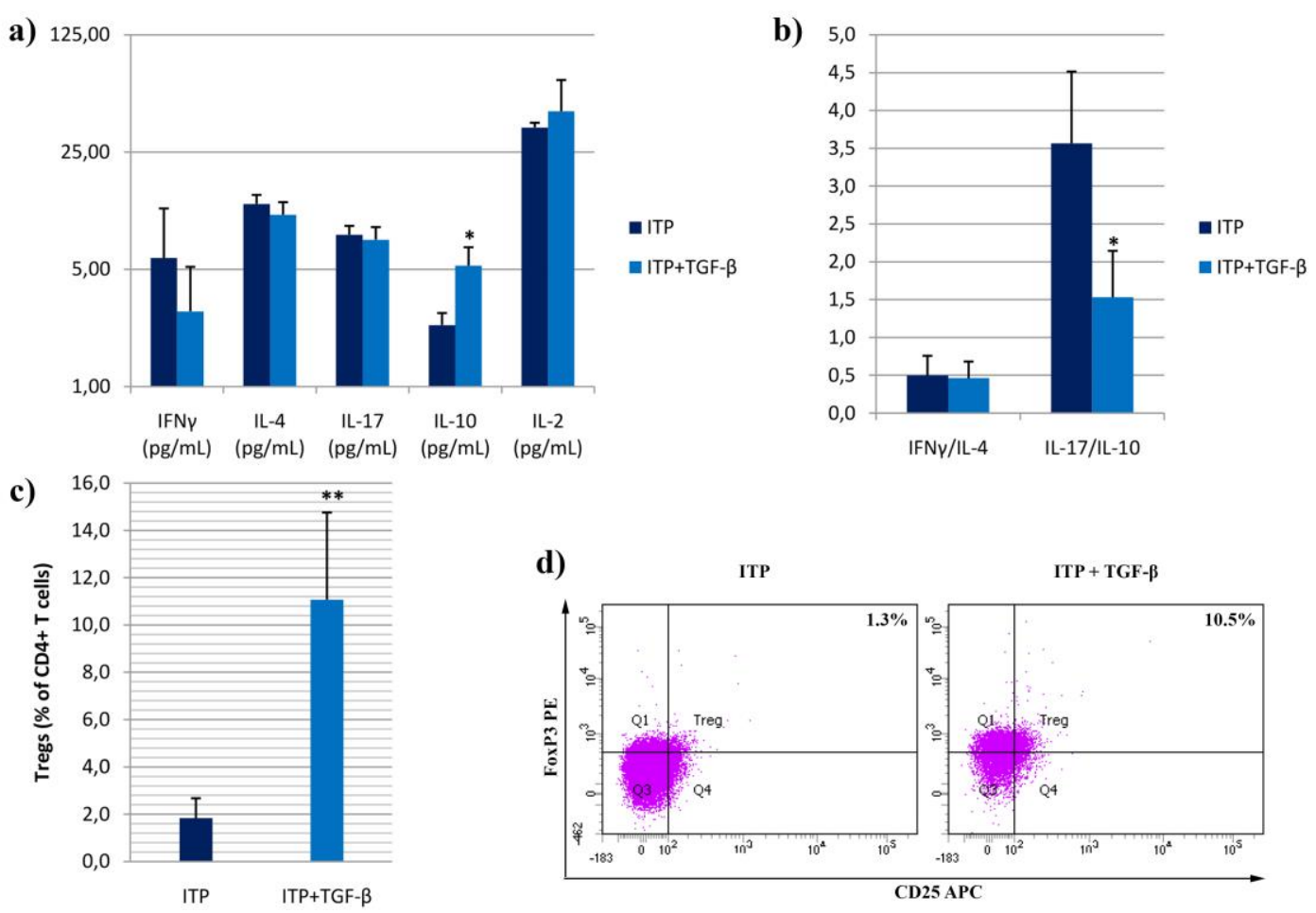

Figure 3. $\mathrm{CD}^{+} \mathrm{T}$ cell profile of ITP patients after 6-day incubation with TGF- $\beta^{\diamond}$

${ }^{\diamond} \mathrm{CD} 4{ }^{+} \mathrm{T}$ cells isolated from the ITP group were cultured for 6 days with or without TGF- $\beta$ ( $3 \mathrm{ng} / \mathrm{mL}$ ) and stimulated with PMA and ionomycin $8 \mathrm{~h}$ prior supernatant sampling. In collected supernatants: a) the level of Th signature cytokines was determined; b) IFNy/IL-4 and IL-17/IL-10 ratio was calculated; $c$ ) in the remaining cells, Treg frequency was reported; d) representative flow cytometric analyses of CD4 ${ }^{+} \mathrm{T}_{\text {cells }}$ in one experiment. (*p $<0.05 ; * * p<0.01$ versus ITP)

a) 125,00

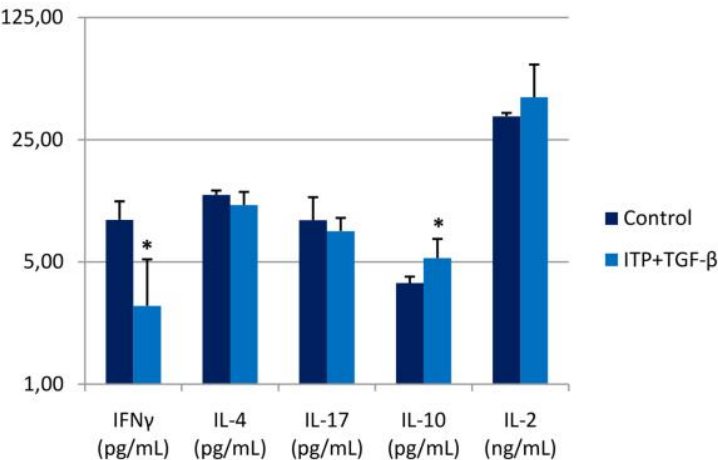

c)

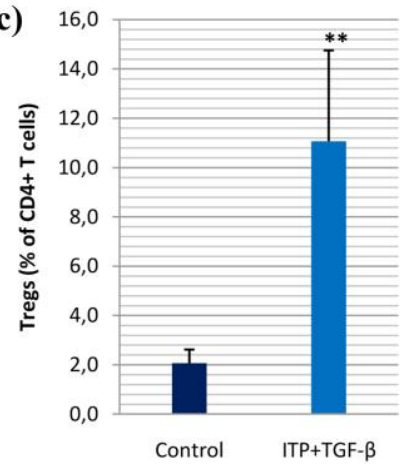

b)

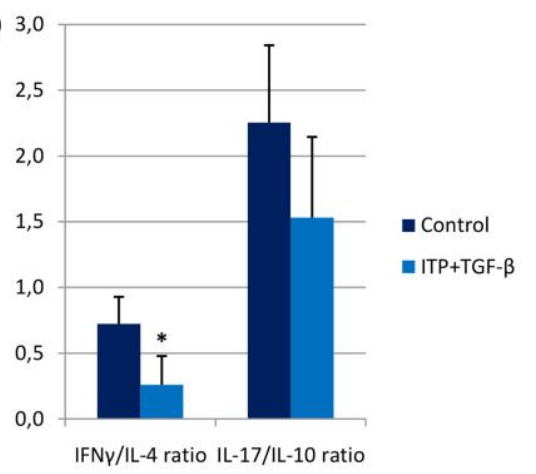

Figure 4. Immunomodulatory effects of TGF- $\beta$ in ITP patients compared with healthy controls ${ }^{\Delta}$

${ }^{\Delta} \mathrm{CD} 4^{+} \mathrm{T}$ cells isolated from the ITP patients treated with TGF- $\beta$ ( $\left.3 \mathrm{ng} / \mathrm{mL}\right)$ and untreated $\mathrm{CD} 4^{+} \mathrm{T}$ cells obtained from healthy controls were cultured for 6 days and stimulated with PMA and ionomycin 8 h prior supernatant sampling. In collected supernatants: a) the level of Th signature cytokines was determined; b) IFNY/IL-4 and IL-17/IL-10 ratio was calculated; c) in the remaining cells, Treg frequency was reported; d) representative flow cytometric analyses of $\mathrm{CD}^{+} \mathrm{T}$ cells in one experiment. $(* \mathrm{p}<0.05 ; * * \mathrm{p}<0.01$ versus control) 


\section{Discussion}

Currently, the abnormalities of $\mathrm{CD}^{+}{ }^{+} \mathrm{T}$ cell compartment in patients with ITP are well established (25). Accordingly, in our study, we have also observed Th1 and Th17 polarization of cellular immune response, based on higher cytokine ratio of IFNY/IL-4 and IL-17/IL-10 in the cultures of isolated $\mathrm{CD}^{+} \mathrm{T}$ cells, indicating disturbed balance of both Th1/Th2 and Th17/Treg axes. Similar observations, although using different methodological approaches, such as direct cytokine detection in patient's plasma and the identification of $\mathrm{CD}^{+}{ }^{+} \mathrm{T}$ cell subsets in the blood, were made by other authors (22, 26-28). Interestingly, in these studies, pulsed high-dose dexamethasone treatment was shown to correct reported Th1/Th2 and Th17/Treg immune deviations, further supporting their relevance in the disease pathogenesis $(27,28)$. Patients enrolled in our study were, however, in the remission induced by longterm prednisone therapy and it appeared that immunological pattern of the diseased remained unaItered. This finding might suggest that beneficial effects of prednisone treatment were achieved by non-selective immune suppression rather then the restoration of Th balance. Different non-specific acting mechanisms of prednisone have been previously proposed, including reduced phagocyte capacity to internalize antibody coated platelets (29), reduced anti-platelet antibody production due to lymphotoxic effect (30), and enhanced platelet production (31). Additionally, immunosuppressive effects of corticosteroids mainly result from the inhibition of proinflammatory transcription factors, particularly nuclear factor kappa B (NF-kB) and activating protein-1 (AP-1), which are active during initial $T$ cell priming, regardless of their future differentiation fate, but also in various other cells of both innate and acquired immunity, directly suggesting their non-selective mechanism of action (32).

One of the unexpected findings of our study was that, in contrast to the short-term (24h) cultures, in six-day cultures previously observed difference in the cytokine profile of $\mathrm{CD}^{+}{ }^{+} \mathrm{T}$ cells isolated from ITP patients and healthy controls did not persist, except for IL-10 level which was significantly decreased. Plausibly, the explanation of this effect could be associated with extreme plasticity of these cells, which differentiation state could be considered only in the context of microenvironment conditions. Butch et al. have also shown that peri-pheral blood $\mathrm{T}$ cell subsets do not retain an original pattern of cytokine production during extended culture periods under conventional non-polarizing conditions (33). Thus, the restoration of cytokine balance in ITP group could be a consequence of pro-longed ex vivo cell culturing, which do not mirror conditions present in vivo. Although, this experi-mental model has been used for investigating $\mathrm{CD}^{+} \mathrm{T}$ cell profile of ITP patients (34-36), our results suggest that in vivo studies are required in order to adequately address this issue.

Recently, it has been shown that Th17 cells can trans-differentiate into T regulatory 1 ( $\operatorname{Tr} 1$ ) cells - a specific subset of IL-10 producing $T$ cells with suppressive functions, during a physiological immune 10 response in the presence of TGF- $\beta 1$ (37). Considering that we, as well as others (38), have observed a disturbed IL-17/IL-10 ratio in patients with ITP, TGF- $\beta$ could be a promising immunomodulatory candidate in the restoration of immunological tolerance in ITP. Furthermore, in both adult and pediatric ITP patients, the plasma levels of TGF- $\beta$ were found to be decreased, positively correlated with the platelet counts but negatively with the levels of proinflammatory IFNy and IL-17 (17, 18, 20). Indeed, in our study, TGF- $\beta$ treatment induced a decrease of IL-17/IL-10 ratio, primarily due to enhanced production of IL-10. In order to investigate potential cellular source of enhanced IL-10 production, we have examined the frequency of Tregs which are also well established IL-10 producers, and shown a significant increase following TGF- $\beta$ treatment. When compared with the untreated control group, the TGF- $\beta$ treated ITP group had decreased IFNy/IL-4 ratio as well as increased $\mathrm{IL}-10$ production and Treg frequency suggesting that TGF- $\beta$ induces polarization of cellular immune response toward more tolerogenic phenotype. Thus, enhancing TGF- $\beta$ signaling in ITP patients could be a promising therapeutic strategy and some initial efforts in this direction have been made. Specifically, all-trans retinoic acid (ATRA) has been shown to be capable of promoting Treg development and their suppressive capacity, simultaneously inhibiting Th17 differentiation by enhancing TGF- $\beta$ signaling (39-41). Furthermore, ATRA was able to restore macrophagal $M 1 / M 2$ imbalance documented in ITP towards M2 phenotype, which development and function are also related to the TGF- $\beta$ signaling $(42,43)$. In the study of Dai et al., ATRA therapy proved to be efficient in ITP treatment, considering significant increase of Treg percentage and IL-10 levels, which is in line with our results observed after TGF- $\beta$ treatment. Unfortunately, in this study TGF- $\beta$ levels were not evaluated (44).

\section{Conclusion}

Our data reconfirm deviant polarization of $\mathrm{CD}^{+}{ }^{+} \mathrm{T}$ cells in ITP patients and suggest that TGF- $\beta$ could restore disturbed Th1/Th2 and Th17/Treg balance, indicating that enhancing TGF- $\beta$ signaling could be a promising therapeutic strategy. However, the study also raises a concern about prolong $\mathrm{CD}^{+}$ $T$ cell cultures as a model of studying the phenotype characteristics of these cells, considering their spontaneous phenotype fluctuations in ex vivo conditions.

\section{Acknowledgments}

This paper was supported by the Ministry of Education, Science and Technological Development of the Republic of Serbia, under the project number 41018 and the Faculty of Medicine, University of Niš, Serbia under the project number 30.

\section{Declarations of interest}

None. 


\section{References}

1. Nugent D, McMillan R, Nichol JL, Slichter SJ. Pathogenesis of chronic immune thrombocytopenia: increased platelet destruction and/or decreased platelet production. Br J Haematol 2009;146(6):585-96. [CrossRef] [PubMed]

2. McMillan R. Antiplatelet antibodies in chronic adult immune thrombocytopenic purpura: assays and epitopes. J Pediatr Hematol Oncol 2003;25 Suppl 1:S5761. [CrossRef] [PubMed]

3. Roark JH, Bussel JB, Cines DB, Siegel DL. Genetic analysis of autoantibodies in idiopathic thrombocytopenic purpura reveals evidence of clonal expansion and somatic mutation. Blood 2002;100(4):138898. [CrossRef] [PubMed]

4. Sukati H, Watson HG, Urbaniak SJ, Barker RN. Mapping helper T-cell epitopes on platelet membrane glycoprotein IIIa in chronic autoimmune thrombocytopenic purpura. Blood 2007;109(10):4528-38. [CrossRef] [PubMed]

5. Semple JW, Freedman J. Increased antiplatelet $T$ helper lymphocyte reactivity in patients with autoimmune thrombocytopenia. Blood 1991;78(10): 2619-25. [CrossRef] [PubMed]

6. Shan NN, Zhu XJ, Peng J, Qin P, Zhuang XW, Wang $\mathrm{HC}$, et al. Interleukin 18 and interleukin 18 binding protein in patients with idiopathic thrombocytopenic purpura. Br J Haematol 2009;144(5):755-61. [CrossRef] [PubMed]

7. Yao $R$, Lin $Y$, Li $Q$, Zhou $X$, Pan $X$, Bao $Y$, et al. Downregulation of T-bet/GATA-3 ratio induced by IL11 treatment is responsible for Th1/Th2 balance restoration in human immune thrombocytopenic purpura (ITP). J Thromb Thrombolysis 2014;38(2):183-9. [CrossRef] [PubMed]

8. Wang $\mathrm{T}$, Zhao $\mathrm{H}$, Ren $\mathrm{H}$, Guo J, Xu M, Yang $\mathrm{R}$, et al. Type 1 and type 2 T-cell profiles in idiopathic thrombocytopenic purpura. Haematologica 2005;90(7):91423. [CrossRef] [PubMed]

9. Takahashi N, Saitoh T, Gotoh N, Nitta Y, Alkebsi L, Kasamatsu $T$, et al. The cytokine polymorphisms affecting Th1/Th2 increase the susceptibility to, and severity of, chronic ITP. BMC Immunol 2017;18(1): 26. [CrossRef] [PubMed]

10. Panitsas FP, Theodoropoulou $M$, Kouraklis A, Karakantza M, Theodorou GL, Zoumbos NC, et al. Adult chronic idiopathic thrombocytopenic purpura (ITP) is the manifestation of a type- 1 polarized immune response. Blood 2004;103(7):2645-7. [CrossRef] [PubMed]

11. Li F, Zou S, Cheng Y. Elevated Expression of IL-17 and IL-23 in Patients with Immune Thrombocytopenic Purpura. Blood 2008;112:4537. [CrossRef]

12. Rocha AM, Souza C, Rocha GA, de Melo FF, Clementino NC, Marino MC, et al. The levels of IL-17A and of the cytokines involved in Th17 cell commitment are increased in patients with chronic immune thrombocytopenia. Haematologica 2011;96(10):1560-4. [CrossRef] [PubMed]

13. Ye $X$, Zhang $L$, Wang $H$, Chen $Y$, Zhang W, Zhu R, et al. The role of IL-23/Th17 pathway in patients with primary immune thrombocytopenia. PLoS One 2015; 10(1):e0117704. [CrossRef] [PubMed]

14. Hua F, Ji L, Zhan Y, Li F, Zou S, Chen L, et al. Aberrant frequency of IL-10-producing $B$ cells and its association with Treg/Th17 in adult primary immune thrombocytopenia patients. Biomed Res Int 2014; 2014:571302. [CrossRef] [PubMed]

15. Liu B, Zhao H, Poon MC, Han Z, Gu D, Xu M, et al. Abnormality of $\mathrm{CD} 4(+) \mathrm{CD} 25(+)$ regulatory $T$ cells in idiopathic thrombocytopenic purpura. Eur J Haematol 2007;78(2):139-43. [CrossRef] [PubMed]

16. Sakakura M, Wada H, Tawara I, Nobori T, Sugiyama $\mathrm{T}$, Sagawa N, et al. Reduced Cd4+Cd25+ T cells in patients with idiopathic thrombocytopenic purpura. Thromb Res 2007;120(2):187-93. [CrossRef] [PubMed]

17. Bao W, Bussel JB, Heck S, He W, Karpoff M, Boulad N, et al. Improved regulatory T-cell activity in patients with chronic immune thrombocytopenia treated with thrombopoietic agents. Blood 2010;116(22):4639-45. [CrossRef] [PubMed]

18. Andersson PO, Stockelberg D, Jacobsson S, Wadenvik H. A transforming growth factor-beta1-mediated bystander immune suppression could be associated with remission of chronic idiopathic thrombocytopenic purpura. Ann Hematol 2000;79(9):507-13. [CrossRef] [PubMed]

19. Li F, Ji L, Wang W, Hua F, Zhan Y, Zou S, et al. Insufficient secretion of IL-10 by Tregs compromised its control on over-activated CD4+ T effector cells in newly diagnosed adult immune thrombocytopenia patients. Immunol Res 2015;61(3):269-80.

[CrossRef] [PubMed]

20. Wang JD, Chang TK, Lin HK, Huang FL, Wang CJ, Lee $\mathrm{HJ}$. Reduced expression of transforming growth factor$\beta 1$ and correlated elevation of interleukin-17 and interferon- $\gamma$ in pediatric patients with chronic primary immune thrombocytopenia (ITP). Pediatr Blood Cancer 2011;57(4):636-40. [CrossRef] [PubMed]

21. Zhou L, Lopes JE, Chong MM, Ivanov II, Min R, Victora GD, et al. TGF-beta-induced Foxp3 inhibits $T(H) 17$ cell differentiation by antagonizing RORgammat function. Nature 2008;453(7192):236-40.

[CrossRef] [PubMed]

22. Ji L, Zhan Y, Hua F, Li F, Zou S, Wang W, et al. The Ratio of Treg/Th17 Cells Correlates with the Disease Activity of Primary Immune Thrombocytopenia. PLoS One 2012;7(12):e50909. [CrossRef] [PubMed]

23. Downs-Canner S, Berkey S, Delgoffe GM, Edwards RP, Curiel $T$, Odunsi $K$, et al. Suppressive IL-17A ${ }^{+}$Foxp $3^{+}$ and ex-Th17 IL-17A-Foxp3 ${ }^{+}$Treg cells are a source of tumour-associated Treg cells. Nat Commun 2017;8: 14649. [CrossRef] [PubMed]

24. Rodeghiero F, Stasi R, Gernsheimer T, Michel $M$, Provan D, Arnold DM, et al. Standardization of terminology, definitions and outcome criteria in immune thrombocytopenic purpura of adults and children: report from an international working group. Blood 2009;113(11):2386-93. [CrossRef] [PubMed]

25. Swinkels M, Rijkers M, Voorberg J, Vidarsson G, Leebeek FWG, Jansen AJG. Emerging Concepts in Immune Thrombocytopenia. Front Immunol 2018;9: 880. [CrossRef] [PubMed]

26. Ogawara $\mathrm{H}$, Handa $\mathrm{H}$, Morita $\mathrm{K}$, Hayakawa M, Kojima J, Amagai $\mathrm{H}$, et al. High Th1/Th2 ratio in patients with chronic idiopathic thrombocytopenic purpura. Eur J Haematol 2003;71(4):283-8. [CrossRef] [PubMed]

27. Guo C, Chu X, Shi Y, He W, Li L, Wang L, et al. Correction of Th1-dominant cytokine profiles by highdose dexamethasone in patients with chronic 
idiopathic thrombocytopenic purpura. J Clin Immunol 2007;27(6):557-62. [CrossRef] [PubMed]

28. Li J, Wang Z, Hu S, Zhao X, Cao L. Correction of abnormal $T$ cell subsets by high-dose dexamethasone in patients with chronic idiopathic thrombocytopenic purpura. Immunol Lett 2013;154(1-2):42-8. [CrossRef] [PubMed]

29. Handin RI, Stossel TP. Effect of corticosteroid therapy on the phagocytosis of antibody-coated platelets by human leukocytes. Blood 1978;51(5):771-9. [CrossRef] [PubMed]

30. Fujisawa K, Tani P, Piro L, McMillan R. The effect of therapy on platelet-associated autoantibody in chronic immune thrombocytopenic purpura. Blood 1993; 81(11):2872-7. [CrossRef] [PubMed]

31. Houwerzijl EJ, Blom NR, van der Want JJ, Esselink MT, Koornstra JJ, Smit JW, et al. Ultrastructural study shows morphologic features of apoptosis and paraapoptosis in megakaryocytes from patients with idiopathic thrombocytopenic purpura. Blood 2004; 103 (2):500-6. [CrossRef] [PubMed]

32. Vandevyver S, Dejager L, Tuckermann J, Libert C. New Insights into the Anti-inflammatory Mechanisms of Glucocorticoids: An Emerging Role for Glucocorticoid-Receptor-Mediated Transactivation. Endocrinology 2013;154(3):993-1007. [CrossRef] [PubMed]

33. Butch AW, Pesando J, Levine AD, McKearn JP, Nahm $\mathrm{MH}$. Cytokine production by $\mathrm{T}$ helper cell subpopulations during prolonged in vitro stimulation. Immunol Lett 1991;27(2):85-93. [CrossRef] [PubMed]

34. Shan NN, Ji XB, Wang X, Li Y, Liu X, Zhu XJ, et al. In vitro recovery of Th1/Th2 balance in PBMCs from patients with immune thrombocytopenia through the actions of IL-18BPa/Fc. Thromb Res 2011;128(6): e119-24. [CrossRef] [PubMed]

35. Ge F, Zhang Z, Hou J, Cao F, Zhang Y, Wang P, et al. Granulocyte colony-stimulating factor decreases the Th1/Th2 ratio in peripheral blood mononuclear cells from patients with chronic immune thrombocytopenic purpura in vitro. Thromb Res 2016;148:76-84. [CrossRef] [PubMed]

36. Yu S, Liu C, Li L, Tian T, Wang M, Hu Y, et al. Inactivation of Notch signaling reverses the Th17/Treg imbalance in cells from patients with immune thrombocytopenia. Lab Invest 2015;95(2):157-67. [CrossRef] [PubMed]

37. Gagliani N, Amezcua Vesely MC, Iseppon A, Brockmann L, Xu H, Palm NW, et al. Th17 cells transdifferentiate into regulatory $\mathrm{T}$ cells during resolution of inflammation. Nature 2015;523(7559):221-5. [CrossRef] [PubMed]

38. Zhou L, Xu F, Chang C, Tao Y, Song L, Li X. Interleukin-17-producing CD4+ $\mathrm{T}$ lymphocytes are increased in patients with primary immune thrombocytopenia. Blood Coagul Fibrinolysis 2016;27(3): 3017. [CrossRef] [PubMed]

39. Mucida D, Park Y, Kim G, Turovskaya O, Scott I, Kronenberg $\mathrm{M}$, et al. Reciprocal TH17 and regulatory $\mathrm{T}$ cell differentiation mediated by retinoic acid. Science 2007;317(5835):256-60. [CrossRef] [PubMed]

40. Lu L, Ma J, Li Z, Lan Q, Chen M, Liu Y, et al. All-trans retinoic acid promotes TGF- $\beta$-induced Tregs via histone modification but not DNA demethylation on Foxp3 gene locus. PLoS One 2011;6(9):e24590. [CrossRef] [PubMed]

41. Mucida D, Pino-Lagos K, Kim G, Nowak E, Benson MJ, Kronenberg $M$, et al. Retinoic acid can directly promote TGF-beta-mediated Foxp3(+) Treg cell conversion of naive $T$ cells. Immunity 2009;30(4):471-2. [CrossRef] [PubMed]

42. Feng $Q, X u M, Y u Y Y$, Hou $Y, M i X$, Sun $Y X$, et al. Highdose dexamethasone or all-trans-retinoic acid restores the balance of macrophages towards M2 in immune thrombocytopenia. J Thromb Haemost 2017;15(9): 1845-1858. [CrossRef] [PubMed]

43. Zhang $F$, Wang $H$, Wang $X$, Jiang $G$, Liu $H$, Zhang $G$, et al. TGF- $\beta$ induces M2-like macrophage polarization via SNAIL-mediated suppression of a pro-inflammatory phenotype. Oncotarget 2016;7(32):5229452306. [CrossRef] [PubMed]

44. Dai L, Zhang R, Wang Z, He Y, Bai X, Zhu M, et al. Efficacy of immunomodulatory therapy with all-trans retinoid acid in adult patients with chronic immune thrombocytopenia. Thromb Res 2016;140:73-80. [CrossRef] [PubMed] 


\title{
IMUNOMODULACIJSKA SVOJSTVA TGF- $\beta$ KOD BOLESNIKA SA IMUNSKOM TROMBOCITOPENIJOM
}

\author{
Miloš Kostić ${ }^{1}$, Tanja Džopalić ${ }^{1}$, Nikola Živković2 ${ }^{2}$ Ana Cvetanović3
}

${ }^{1}$ Univerzitet u Nišu, Medicinski fakultet, Katedra za mikrobiologiju i imunologiju, Niš, Srbija

${ }^{2}$ Univerzitet u Nišu, Medicinski fakultet, Katedra za patologiju, Niš, Srbija

${ }^{3}$ Univerzitet u Nišu, Medicinski fakultet, Katedra za onkologiju, Niš, Srbija

Kontakt: Miloš Kostić

Bulevar dr Zorana Đinđića 81, 18000 Niš, Srbija

E-mail: milos.kostic@medfak.ni.ac.rs

Novi koncept patogeneze imunske trombocitopenije (ITP) fokusiran je na CD4 ${ }^{+} \mathrm{T}$ ćelije, koje se trenutno smatraju krucijalnim u stimulisanju B ćelija na produkciju antitrombocitnih antitela. $U$ ovoj in vitro studiji istraživali smo profil $\mathrm{CD}^{+} \mathrm{T}$ ćelija obolelih od ITP i imunomodulacijska svojstva TGF- $\beta$. CD4 ${ }^{+} \mathrm{T}$ ćelije izolovane su iz mononuklearnih ćelija periferne krvi zdravih ispitanika i ispitanika obolelih od ITP. Nakon kratkotrajne inkubacije, određeni su nivoi osnovnih citokina $T$ pomoćničkih ćelija, kao i broj $T$ regulatornih ćelija (Treg). Imunomodulacijska svojstva TGF- $\beta$ analizirana su praćenjem izmena u produkciji citokina IFNy, IL-4, IL-10, IL-17 i IL-2, kao i učestalosti Treg, nakon šestodnevnog tretmana. Oboleli od ITP imali su smanjen nivo IL-4 i IL-10, povećan nivo IL-17, kao i povišen odnos IFNy/IL-4 i IL-17/IL10. Zanimljivo je to da u šestodnevnim $C D 4^{+} \mathrm{T}$ ćelijskim kulturama, bez TGF- $\beta$ tretmana, nisu evidentirane statistički značajne razlike u nivou citokina između ispitanika kontrolne i ITP grupe, osim nivoa IL-10, koji je bio značajno niži. U ITP grupi ispitanika, nakon TGF- $\beta$ tretmana, registrovano je značajno povećanje IL-10, kao i smanjenje odnosa IL-17/IL-10 u poređenju sa ispitanicima ITP grupe, koji nisu tretirani na ovaj način. Takođe, primećena je povećana učestalost Treg. Rezultati naše studije sugerišu na to da oboleli od ITP pokazuju aberantnu Th1 i Th17 polarizaciju celularnog imunskog odgovora, što se može korigovati stimulisanom TGF- $\beta$ signalizacijom. Međutim, ispostavlja se da dugotrajna kultivacija CD4 ${ }^{+} \mathrm{T}$ ćelija nije pogodan eksperimentalni model za proučavanje imunomodulatornih svojstava u ITP, usled dinamičkih fluktuacija fenotipa ovih ćelija u ex vivo uslovima.

Acta Medica Medianae 2020;59(2):05-13.

Ključne reči: imunska trombocitopenija; TGF- $\beta$; imunomodulacija; IL-10, IL-17 